\title{
The Difference in Salivary Flow Rate Before and After Stimulate Between Chewing Pineapple (Ananas comocus) dan Papaya (Carica papaya)
}

\author{
Zulfan M.Alibasyah, Sri Rezeki², Trisna Fitri
}

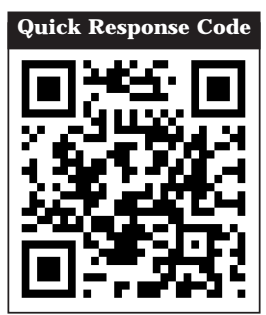

doi: $10.5866 / 2017.9 .10082$

${ }^{1}$ Departement of Periodontology

2Departement of Oral Medicine

Faculty of Dentistry, University of Syiah Kuala,

Banda Aceh, Indonesia

3Student of Dentistry Faculty, University of Syiah Kuala, Banda Aceh, Indonesia

\section{Article Info:}

Received: April 10, 2017

Review Completed: May 11, 2017

Accepted: J une 12, 2017

Available Online: J une, 2017 (www.nacd.in)

(C) NAD, 2017 - All rights reserved

\section{Email for correspondence:}

zulfanmalibasyah@gmail.com

\begin{abstract}
:
Context: Salivary flow rate is a measure of salivary flow rate in $\mathrm{ml} / \mathrm{minute}$ that collected in the oral cavity. Salivary flow rate can be increased by using different stimuli such as mechanical and chemical stimuli. One natural way to increase the sal ivary flow is to use pineapple and papaya. Pineapple and papaya is a fruit that is consumed daily.
\end{abstract}

Aims \& Objectives: The purpose of the study is to examine changes in the salivary flow rate students of the Faculty of Dentistry, University of Syiah Kuala force in 2013-2016 before and after chewing pinneapple (Ananas comocus) and papaya (Carica papaya).

Materials \& Methods: Type of research is pre-experimental research with two group pretest post test design. The population in this study were all of the students in Faculty of Dentistry, University of Syiah Kuala. Subjects included in the criteria for inclusion of 100 people.

Results: The results of data analysis on a statistical test by paired $t$ test showed that there are differences in salivary flow rate between before and after chewing pineapple (Ananascomocus) with a value of $p=0,000(p<0.05)$ and there are differences in salivary flow rate between before and after chewing papaya (Carica papaya) with a value of $p=0.000(p<0.05)$ and also independent sample test showed a significant difference between the flow rate of sal iva after chewing pineapple (Ananascomocus) and after chewing papaya (Carica papaya) with a value of $p=0.035(p<0.05)$.

Conclusion: The study concluded that chewing pineapple can increase salivary flow rates higher than chewing papaya.

Key words: Pineapple (Ananas comocus), papaya (Carica papaya), salivary flow rate

\section{INTRODUCTION}

Saliva is the mixture of fluids that originates from major and minor salivary glands and nonglandular sources such as crevicular fluids, oral microorganism, and host cells. ${ }^{1}$ Saliva is importance to maintain oral health, and saliva has multiple functions. $^{2}$

Saliva have two functions that is digestive and protective functions and additional functions. ${ }^{3}$ Digestive functions include chewing of food, bolus

\section{Indian Journal of Dental AdVAncements}

Journal homepage: www. nacd. in 
formation, and swallowing. To the protective functions include self cleansing, lubricate the oral tissues by mucins, ${ }^{1}$ ability of the buffer to maintain salivary $\mathrm{pH}$ around 7.0, and antimicrobial action. ${ }^{3}$ Additional functions include articulate speech and excretion. ${ }^{3}$ Saliva is very influential on the dental health because of the chemical composition, the buffer capacity (buffer), antimicrobial activity, and salivary flow rate (flow rate). ${ }^{4}$

Salivary flow rate can be obtained with or without stimulus, that is the stimulated and the unstimulate salivary flow. ${ }^{5}$ Reduced salivary flow rate can be cause impedes the mastication and swallowing of food, neutralization of acids, and leads to oral diseases such mucosal lesions, caries, candidiasis, gingivitis, and periodontal diseases. 6,7

One effort that can be done to overcome the problem of reduced salivary flow is by stimulating saliva with citric acid and vitamin $C$ in patients xerostomia. ${ }^{5,8}$ Citric acid content is widely available in the pineappleand papaya with citric acid content of $346 \mathrm{mg}$ pineapple and papaya is $335 \mathrm{mg} .^{9}$ Pineapple and papaya also contains vitamin $C$ with the $24 \mathrm{mg}$ pineapple and papaya is $61.8 \mathrm{mg}^{10,11}$ Lewapadang et al (2015) research stated that the consumption of pineapple juice in the elderly can reduce xerostomia and increase secretion saliva. ${ }^{12}$ Widya research (2013)that eating papaya can lower the debris index, and to chew papaya can stimulate to produce more saliva. ${ }^{13}$ The present study was aimed to determine the presence of differences in salivary flow before and after stimulation between chewing pineapple (Ananascomocus) and chew papaya (Carica papaya).

\section{METHODS}

Type of research is pre-experimental study with two group pretest posttest design. This research was conducted in the building of theF aculty of Dentistry Unsyiah. The sample in the present study were all students from Faculty of Dentistry, University of Syiah Kuala. Subjects who met the inclusion criteria obtained as many as 100 people.

Subjects were instructed not to eat, drink, chew, smoking, brush of teeth, and physical exercise for at least one hour prior to the saliva collection time. ${ }^{14}$ Saliva collection were obtained at 9-11 am, in a ventilated and well illuminated room. ${ }^{5}$ The first group was given 100 grams of pineapple that has been cut and the second group was given papaya
100 grams. Both groups were asked to chew pineappleand papaya for 2 minutes, then given time to rest for 5 minutes. Spitting saliva collection methods were conducted with a total of 5 minutes, with the way the subjects were instructed to remain silent for one minute, then every 1 minute subjects were asked to remove the accumulated saliva in the mouth and ejected into a measuring cup. ${ }^{15}$

\section{RESULTS}

Resultof difference in salivary flow rate before and after stimulation between chewing pineapple and chewing papaya on the students of the Faculty of Dentistry, U niversity of Syiah Kuala generation from 2013 to 2016.

Data about salivary flow rate before and after chewing pineapple (Ananascomocus) and flow rate of saliva before and after chewing papaya (Carica papaya) tested the normality using the Shapiro-Wilk test. Normality test results demonstrate the significant value of salivary flow were obtained before and after chewing pineapple (Ananascomocus) and flow rate of saliva before and after chewing papaya (Carica papaya) $p>0.05$, which indicates that the normal distribution of data.

Table 1.1. Normality test of salivary flow rate

$\begin{array}{lc}\text { Difference } & \begin{array}{c}\text { Number of } p \\ \text { Subject }\end{array}\end{array}$

Salivary flow rate before

and after chewing

pineapple (Ananascomocus) $50 \quad 0,118$

salivary flow rate before

and after chewing papaya

(Carica papaya)

50

0,053

The results of the analysis of differences in salivary flow before and after chewing pineapple (Ananascomocus) showed a significant result ( $p$ $\varangle 0.05)$.

Table 1.2. Results of difference salivary flow rate before and after chewing pineapple

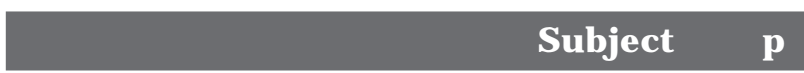

Salivary flow rate before and after chewing pineapple (Ananas comocus) $50 \quad 0,0000$

The results of the analysis of differences in salivary flow before and after chewing papaya (Carica papaya) showed a significant result $(p \varangle 0.05)$. 
Table 1.3. Results of difference salivary flow rate before and after chewing papaya

\section{Subject}

p

Salivary flow rate before

and after chewing papaya

(Carica papaya)

$50 \quad 0,0000$

The results of the analysis of average in salivary

flow before and after chewing pineapple (Ananas comocus)) showed difference is 0,4460 .

Table 1.4. Results of average salivary flow rate before and after chewing pineapple

\begin{tabular}{lcc} 
& Subject & $\begin{array}{c}\text { Average } \\
\begin{array}{l}\text { Salivary flow rate before } \\
\text { chewing pineapple }\end{array}\end{array}$ \\
$\begin{array}{l}\text { Salivary flow rateafter } \\
\text { chewing pineapple }\end{array}$ & 50 & 0,3520 \\
$\begin{array}{l}\text { (Ananas comocus) } \\
\text { Salivary flow rate before } \\
\text { and after chewing pineapple } \\
\text { (Ananas comocus) }\end{array}$ & 50 & 0,7980 \\
\hline
\end{tabular}

The results of theanalysis of average in salivary flow before and after chewing pineapple (Ananas comocus)) showed difference is 0,4460 .

\section{Table 1.5. Results of average salivary flow rate before and after chewing papaya}

\section{Subject Average}

Salivary flow rate before

chewing papaya

(Carica papaya)

$50 \quad 0,2840$

Salivary flow rateafter chewing papaya

(Carica papaya)

$50 \quad 0,7000$

Salivary flow rate before and after chewing papaya (Carica papaya)

$50 \quad 0,4160$

To determine difference in salivary flow rate after chewing pineapple with salivary flow rate after chewing papaya then tested the T unpaired against both results are pineapple (Ananascomocus) different from papaya (Carica papaya). Unpaired T test results obtained significance value of $p<0.05$.
Table 1.6. Result of difference salivary flow rate after chewing pineapple and papaya

\begin{tabular}{lcl} 
Variable 1 & $\mathbf{P}$ & Variabel $\mathbf{2}$ \\
Salivary flow rate & $\mathbf{0 , 0 3 5}$ & $\begin{array}{l}\text { Salivary flow rate } \\
\text { after chewing }\end{array}$ \\
pineapple & & $\begin{array}{l}\text { papaya (Carica } \\
\text { (Ananas comocus) }\end{array}$ \\
\hline
\end{tabular}

\section{DISCUSSION}

This study was conducted to see the effect of chewing pineapple (Ananascomocus) and papaya (Carica papaya) against salivary flow.

Table 1.2 shows the differences in salivary flow before and after stimulation of chewing pineapple (Ananascomocus). This is related to a chemical stimulus in the form of citric acid that is found in pineapple, where the acid is the most powerful stimulus in increasing the secretion saliva ${ }^{16}$ and to chewing pineapple as a mekanis stimulus. ${ }^{2}$ This is in accordance with Lewapadang W et al (2015) stated that the citric acid content pineapple fruit can stimulate the salivary glands are parotid, submandibular, sublingual, and minor glands. ${ }^{12}$

Table 1.2. shows that there are differences in sal ivary flow before and after stimulation of chewing papaya (Carica papaya). This is related to a chemical stimulus in the form of citric acid and vitamin $\mathrm{C}$ in papaya as well as chewing movements papaya. ${ }^{2,5}$, ${ }^{12}$ Visvanathan (2010) stated that vitamin C in pineapple and papaya can increase the saliva flow rate. ${ }^{8,10,11}$

This study shows there are differences in salivary flow rate after stimulation of chewing pineapple (Ananascomocus) and papaya (Carica papaya), with a flow rate of saliva after chewing pineapple (Ananascomocus) higher than after chewing papaya (Carica papaya). Ana (2010) states that the greater the concentration of citric acid causes the salivary vol ume increased to higher than citric acid in a concentration low. ${ }^{17}$ This is consistent with citric acid content is higher in the $346 \mathrm{mg}$ in pineapple compared in papaya is $335 \mathrm{mg} .{ }^{9}$

\section{CONCLUSIONS}

1. There are differences in salivary flow beforeand after stimulation of chewing pineapple (Ananascomocus).

2. There are differences in salivary flow before and after stimulation chewing papaya (Carica papaya). 


\section{RESULT OF DATA EXAMINATION}

\begin{tabular}{|c|c|c|c|c|c|c|}
\hline $\begin{array}{l}\text { Num- } \\
\text { ber }\end{array}$ & $\begin{array}{c}\text { Pineapple } \\
\text { Before } \\
\text { chewing } \\
\text { pineapple }\end{array}$ & $\begin{array}{c}\text { Papaya } \\
\text { After } \\
\text { chewing } \\
\text { pineapple }\end{array}$ & $\begin{array}{l}\text { Diffe- } \\
\text { rence }\end{array}$ & $\begin{array}{c}\text { Before } \\
\text { chewing } \\
\text { papaya }\end{array}$ & $\begin{array}{l}\text { After } \\
\text { chewing } \\
\text { papaya }\end{array}$ & $\begin{array}{l}\text { Diffe } \\
\text { rence }\end{array}$ \\
\hline 1 & 0,2 & 0,5 & 0,3 & 0,2 & 0,5 & 0,3 \\
\hline 2 & 0,3 & 0,7 & 0,4 & 0,3 & 0,4 & 0,1 \\
\hline 3 & 0,4 & 0,5 & 0,1 & 0,3 & 0,6 & 0,3 \\
\hline 4 & 0,3 & 0,6 & 0,3 & 0,3 & 0,8 & 0,5 \\
\hline 5 & 0,3 & 1,0 & 0,6 & 0,4 & 0,9 & 0,5 \\
\hline 6 & 0,3 & 0,4 & 0,1 & 0,3 & 0,8 & 0,5 \\
\hline 7 & 0,3 & 0,6 & 0,3 & 0,3 & 0,4 & 0,1 \\
\hline 8 & 0,2 & 0,5 & 0,3 & 0,3 & 0,4 & 0,1 \\
\hline 9 & 0,4 & 1,1 & 0,7 & 0,2 & 0,6 & 0,4 \\
\hline 10 & 0,3 & 0,8 & 0,5 & 0,3 & 0,5 & 0,2 \\
\hline 11 & 0,5 & 1,0 & 0,5 & 0,2 & 0,9 & 0,7 \\
\hline 12 & 0,4 & 0,5 & 0,1 & 0,2 & 0,4 & 0,2 \\
\hline 13 & 0,5 & 0,6 & 0,1 & 0,3 & 0,8 & 0,5 \\
\hline 14 & 0,4 & 0,7 & 0,3 & 0,3 & 0,5 & 0,2 \\
\hline 15 & 0,4 & 0,9 & 0,5 & 0,5 & 1,0 & 0,5 \\
\hline 16 & 0,5 & 1,0 & 0,5 & 0,3 & 0,6 & 0,3 \\
\hline 17 & 0,4 & 1,1 & 0,7 & 0,3 & 0,9 & 0,6 \\
\hline 18 & 0,3 & 0,5 & 0,2 & 0,3 & 0,5 & 0,2 \\
\hline 19 & 0,3 & 0,8 & 0,5 & 0,2 & 0,5 & 0,3 \\
\hline 20 & 0,3 & 0,6 & 0,3 & 0,3 & 0,8 & 0,5 \\
\hline 21 & 0,3 & 0,7 & 0,4 & 0,1 & 0,3 & 0,2 \\
\hline 22 & 0,5 & 0,8 & 0,3 & 0,3 & 0,6 & 0,3 \\
\hline 23 & 0,3 & 0,9 & 0,6 & 0,5 & 0,9 & 0,4 \\
\hline 24 & 0,4 & 1,1 & 0,7 & 0,3 & 0,8 & 0,5 \\
\hline 25 & 0,3 & 1,0 & 0,7 & 0,3 & 0,3 & 0 \\
\hline 26 & 0,3 & 0,7 & 0,4 & 0,2 & 0,3 & 0,1 \\
\hline 27 & 0,5 & 1,3 & 0,8 & 0,2 & 0,9 & 0,7 \\
\hline 28 & 0,3 & 1,1 & 0,8 & 0,2 & 1,0 & 0,8 \\
\hline 29 & 0,3 & 0,9 & 0,6 & 0,2 & 0,3 & 0,1 \\
\hline 30 & 0,2 & 0,5 & 0,3 & 0,3 & 0,7 & 0,4 \\
\hline 31 & 0,2 & 0,7 & 0,5 & 0,4 & 0,8 & 0,4 \\
\hline 32 & 0,3 & 0,7 & 0,4 & 0,3 & 0,7 & 0,4 \\
\hline 33 & 0,4 & 0,9 & 0,5 & 0,3 & 0,6 & 0,3 \\
\hline 34 & 0,5 & 1,0 & 0,5 & 0,3 & 0,4 & 0,1 \\
\hline 35 & 0,3 & 0,7 & 0,4 & 0,4 & 0,8 & 0,4 \\
\hline 36 & 0,3 & 1,0 & 0,7 & 0,2 & 0,5 & 0,3 \\
\hline 37 & 0,2 & 0,4 & 0,2 & 0,1 & 0,7 & 0,6 \\
\hline 38 & 0,5 & 1,1 & 0,6 & 0,3 & 0,9 & 0,6 \\
\hline 39 & 0,3 & 0,8 & 0,5 & 0,2 & 0,7 & 0,5 \\
\hline 40 & 0,4 & 0,9 & 0,5 & 0,5 & 0,9 & 0,4 \\
\hline 41 & 0,4 & 0,7 & 0,3 & 0,2 & 0,8 & 0,6 \\
\hline 42 & 0,3 & 0,8 & 0,5 & 0,2 & 1,1 & 0,9 \\
\hline 43 & 0,3 & 0,7 & 0,4 & 0,2 & 0,8 & 0,6 \\
\hline 44 & 0,4 & 1,0 & 0,6 & 0,3 & 0,7 & 0,4 \\
\hline 45 & 0,4 & 0,9 & 0,5 & 0,4 & 0,8 & 0,4 \\
\hline 46 & 0,3 & 0,8 & 0,5 & 0,3 & 1,4 & 1,1 \\
\hline 47 & 0,4 & 0,7 & 0,3 & 0,4 & 1,0 & 0,7 \\
\hline 48 & 0,5 & 0,9 & 0,4 & 0,3 & 1,1 & 0,8 \\
\hline 49 & 0,3 & 1,0 & 0,7 & 0,2 & 0,5 & 0,3 \\
\hline 50 & 0,4 & 0,8 & 0,4 & 0,3 & 0,9 & 0,6 \\
\hline
\end{tabular}

3. There are differences in salivary flow with stimulation of chewing pineapple (Ananascomocus) and papaya (Carica papaya), with chewing pineapple (Ananascomocus) can increase the sal ivary flow rate higher than chew papaya (Carica papaya).

\section{REFERENCES}

1. Cruz J C, Scott J, Rothen M, Manci L, Lawhorn T, Brossei $\mathrm{K}, \mathrm{dkk}$. Salivary characteristic and dental caries : Evidence from general dental practices. J Am Dent Assoc 2013;144(5):32.

2. Pedersen AM. Saliva. Institute of Odontology, University of Copenhagen. 2007; 2:6.

3. Ekstrom J, Nina K, Castagnola M, Messana I. Saliva and the control of its secretion. Diagnostic Imaging: Medical Radiology 2012:20-24.

4. Ramadhana S. Perbedaan Iaju aliran saliva sebelum dan sesudah berkumur dengan obat kumur beralkohol pada mahasiswa PSKG unsyiah angkatan 2011-2013. Skripsi Universitas Syiah Kuala 2008:1.

5. Alves $\mathrm{C}, \mathrm{Brandao} \mathrm{M}$, Andion I, Menezes R. Use of graduate syringes for measuring salivary flow rate: A pilot study. Brazilian Dental J ournal 2010; 21(5):1-2.

6. Takeuchi K, Michiko F, Takeshita T, Shibata Y. Risk factors for reduced salivary flow rate in a japanese population: The hisayama study. Biomed Research International 2015; 1-7.

7. Gupta A, Epstein J , Sroussi H. Hyposalivation in elderly patients. J ournal Can Dental Association 2006; 72(9):841-2.

8. Visvanathan V. Managing the patient presenting with xerostomia : a review. International J Clinical Practice2010; 64(3):405.

9. Simmonds M. Nutritional composition of fruit cultivars. 1st ed. Missouri: Elsevier 2015: pp 506-617.

10. Hossain MF, Akhtar S, Anwar M. Nutritional value and medicinal benefits of pineapple. Int J Nutrition Food Sci 2015; 4(1):86.

11. Aravind G, Bhowmik D, Duraivel S, Harish G. Traditional and medicinal uses of Carica papaya. J Med Plant Studies 2013;1(1):8,13.

12. Lewapadang W, Tendean L, Anindita PS. Pengaruh mengonsumsi nanas (Ananas comosus) terhadap laju aliran saliva pada lansia penderita xerostomia. J E-Gigi 2015; 3(2):454.

13. Cahyati WH. Konsumsi pepaya (Carica papaya) dalam menurunkan debris index. J urnal Kesehatan Masyarakat. 2013; 8(2):128-32.

14. Nogourani MK, J anghorbani M, I sfahan RK, Bahesti MH. Effect of chewing different flavored gums on salivary flow rate and $\mathrm{pH}$. International J Dentistry 2012; 1-2.

15. Greenberg M, Glick M, ShipJ A. Burkets oral medicine. 11th ed. Hamilton: BC Decker 2008: pp 194.

16. Indriana T. Perbedaan Iaju aliran saliva dan $\mathrm{pH}$ karena pengaruh stimulus kimiawi dan mekanis. J Kedokt Meditek 2011; 11(44):2.

17. Carolina AS, Ferreira MC. Salivary stimulations by citric acid at concentrations founds in beverages. Conference Paper 2010:1. 